\title{
Tax Loopholes Impact on Canadian Individuals' and Small Business' s Behaviour
}

Yahya Marei*

Department of Applied Arts and Technology, Toronto, Canada

"Corresponding author: Department of Applied Arts and Technology, Toronto, Canada, Tel: 016477613432; E-mail: Yahya.marei@senecacollege.ca

Received Date: Mar 12, 2018; Accepted Date: Jun 22, 2018; Published Date: Jun 30, 2018

Copyright: ( $) 2018$ Yahya M. This is an open-access article distributed under the terms of the Creative Commons Attribution License, which permits unrestricted use, distribution, and reproduction in any medium, provided the original author and source are credited.

\begin{abstract}
Companies are applying different strategies to lower the amount of taxes they remit to the government, but the government seems to be getting lured to their intentions. A policy that came into effect in 2009 allowed Canada to sign agreements related to information exchange on tax with jurisdictions like the Cayman Islands, Isle of Man and Bermuda. The agreement had been intended to allow the government to flush out all individuals hiding their monies in offshore accounts. However, the agreement ended up creating a loophole for big companies to create subsidiaries within such jurisdictions and move their profits home without any form of tax levied on them. US multinationals are always obligated to pay tax wherever they get the international profits. In Canada however, the Tax Information Exchange Agreement shows that it is possible to declare profit generated in a tax haven, where there is very little or no tax, and take it back to the country without the company having to pay any more tax. As such tax treaties have for years encouraged a number of businesses not to operate in Barbados, where the rate of tax is between 1 and 2.5 percent, tax information exchange agreements are believed to have opened up a new chance for legal tax evasion in the zero-tax countries such as Panama, the Bahamas and Bermuda. A number of large corporations on the Stock Exchange of Toronto are now have some presence in tax havens and are applying the Canadian treaty to reduce the amount of tax they pay to the government back at home. Morgan- Thomas reports that one company named Gildan reduced the amount of tax it paid to the government by more than 90 percent just in 2015.
\end{abstract}

Keywords: Business; Corporate; Government; Financial

\section{Introduction}

With the pretext of handling tax evasion in the country, the Canadian government ended up opening a number of tax loopholes that have given Canadian corporations room to evade remitting tax of around $\$ 55$ billion on international profits within the last half a decade [1]. Scholarly reports state that the money is taken through offshore tax havens and is likely to be brought back to Canada tax-free through a number of multinationals in Calgary, Vancouver and Toronto [2]. Scheme done offshores results in the loss of billions of dollars in revenue for the Canadian government, not because the companies are cheating in this case but because the government has established policies which provide loopholes for tax evasion by such corporations.

Since the time the current government was elected, it has always promised to put up a strong fight against tax avoidance and evasion, spending a lot of money on the investigative section of revenue services of Canada. However, Marjit et al. argues that both the present and previous governments have, in one way or another, helped help corporations to evade remitting their share to the government, by converting what had been assumed to be a crackdown into a very big loophole [2]. Scholars' show that, if one is a person/individual business man and has another business is in the form of corporation, then the two are treated differently with reference to tax compliance in the country [1]. As the government has been clamping down on individual taxpayers in the country, it has also been developing emerging tax loopholes for corporate businesses. Morgan-Thomas argued that this has seen a number of corporations in Canada paying absolutely nothing in tax to the government [3].
Stiglitz independently analyzed the financial statements of a number of corporations in Canada, in an attempt to come up with a list of some of the companies that are applying legal mechanisms to achieve huge reductions in their tax rates [4]. For instance, Stiglitz found that the Canadian Pacific Railway only paid a mean of 1.8 percent tax rate in the last ten years, Manitoba Telecom only paid relatively close to 4.0 percent, Gildan Activewear paid 5.4 percent and, lastly, First Capital Realty was reported to have gone for more than ten years without paying anything in the form of taxes to the government [4].

These companies are applying different strategies to lower the amount of taxes they remit to the government, but the government seems to be getting lured to their intentions. A policy that came into effect in 2009 allowed Canada to sign agreements related to information exchange on tax with jurisdictions like the Cayman Islands, Isle of Man and Bermuda [4]. The agreement had been intended to allow the government to flush out all individuals hiding their monies in offshore accounts [2]. However, the agreement ended up creating a loophole for big companies to create subsidiaries within such jurisdictions and move their profits home without any form of tax levied on them.

US multinationals are always obligated to pay tax wherever they get the international profits. In Canada however, the Tax Information Exchange Agreement shows that it is possible to declare profit generated in a tax haven, where there is very little or no tax, and take it back to the country without the company having to pay any more tax [1]. As such tax treaties have for years encouraged a number of businesses not to operate in Barbados, where the rate of tax is between 1 and 2.5 percent, tax information exchange agreements are believed to have opened up a new chance for legal tax evasion in the zero-tax countries such as Panama, the Bahamas and Bermuda. A number of 
large corporations on the Stock Exchange of Toronto are now have some presence in tax havens and are applying the Canadian treaty to reduce the amount of tax they pay to the government back at home. Morgan-Thomas reports that one company named Gildan reduced the amount of tax it paid to the government by more than 90 percent just in 2015 [3].

It is important to note, however, that practices by large corporations in Canada have been a matter of great concern to individuals and small businesses in the country who are obligated to remit their taxes [5]. Scholars point out that small business individuals feel overburdened by the heavy taxes placed on them, while large corporations in the country are enjoying the loopholes of tax avoidance [5]. Though studies have yet to fully explore the topic, it is clear that most Canadian individuals and small businesses will try to avoid paying taxes as they feel they have been treated differently. It is based on this statement that this study seeks to evaluate the impact of tax loopholes on Canadian individuals' and small business's behaviours.

This research is very important as it seeks to investigate the impact that the loopholes enjoyed by corporate organizations have on the general behaviour of individual and small business owners with respect to their attitude and practice of tax evasion. The literature states that, in any given society, where one group of people feels that another group is more favoured than they are, then non-compliance with the set regulations is most likely to occur, especially on the side of the group which feels not favoured [1]. The case will not be any different from the situation in Canada, where small business individuals feel overburden with income taxes while corporations have the opportunity to evade remitting their taxes, thanks to the loopholes created by government policies.

\section{Research Questions or Aims}

The main aim of this study is to identify how tax loopholes impact on Canadian individuals' and small business's behaviour.

This aim includes the following sub-aims:

To determine the extent to which income tax loopholes in Canada encourage individuals and small businesses to avoid paying taxes to provide an understanding of Canadian individuals' and small businesses' behaviours, with regards to income tax loopholes in the country to develop recommendations that encourages the government of Canada to change some of its tax policies and procedures to close the tax loopholes.

\section{Empirical Research Methods}

This research will utilize a cross-sectional study design to collect both qualitative and quantitative data. A cross-sectional study design is defined as one in which study is undertaken only during one point in time, without repeating the same observations for a longer period of time [6]. Other literatures usually refer to it as snap shot study design. The study will be conducted through structured questionnaires administered to a sample of individuals and small business owners in the major towns of Canada. A sample of more than 100 individuals and small business owners will be selected for participation in the study. One major reason why a cross-sectional study design has been chosen for this study is that it is less time consuming and relatively cheap when compared to longitudinal study design [6]. It is important to note, however, that results obtained in this kind of study design only represent the situation on the ground at the time the study is being carried out and cannot be used to argue for what happened afterwards. In simple terms, the researcher will carry out the study at only one single point in time without any further follow-up [6]. Structured questionnaires will be developed in order to obtain the required information from individuals and small business owners regarding their general behaviour towards the income tax loophole in the country.

Both quantitative and qualitative data will be collected and used in this study. While quantitative data will be collected by administering questionnaires to individuals and small business owners in major towns in Canada, secondary data will be used to obtain all the relevant qualitative literature regarding the impact that the Canadian tax loophole has on the behaviours of individuals and small businesses. A structured questionnaire will be designed, based on the research aim of identifying how tax loopholes impact on Canadian individuals' and small business's behaviour. The questionnaire to be used in this case will focus on variable statements that analyse the extent to which income tax loopholes in Canada encourage individuals and small businesses to avoid paying taxes.

The questionnaires will have formulated statements which require those being interviewed to agree or disagree with statements related to the impact of tax loopholes on Canadian individuals' and small business's behaviour. The questionnaire will also have 5-point Likert scale questions, whose answers will range from "1" Strongly Disagree to " 5 " Strongly Agree. For instance, a statement like "I feel encouraged to avoid paying taxes because corporates companies are also avoiding paying them" would be given to the respondents to state whether they Strongly Agree, Agree, are Neutral, Disagree or Strongly Disagree.

It is important to note that a questionnaire will be selected for this study as it is cheap to develop, easy to be filled in by the respondents and analysed by the researcher, unlike other data collection tools, like interview guides which, at times, become too boring for the respondents and are difficult to analyse [6]. The other advantages of using questionnaires are: questionnaires, with confidential participants, help participants better express their opinions, views and convictions without any pressure [7]. It also helps the researcher better quantify results and findings.

The research will target a sample of individuals and small businesses operating in the urban areas of Canada. People in the urban areas are believed to be more informed regarding the status of tax loopholes in the country and hence would reflect the true view of individuals and small business owners regarding the impact of tax loopholes on their behaviour. Only individuals or small business owners will be included in this study. Up to 100 participants will be randomly selected by the researcher and then questionnaires administered to them for filling in and return. The researcher will opt for simple random sampling, as it will minimize any form of bias. A systematic review of the existing literature will also be utilized in this study. This will mostly be intended to obtain insight into the findings from other scholarly research over the same or part of the topic [8]. Even though the strategy of the search will mostly involve scholarly writing, business databases, government reports, articles and newspapers will also be reviewed, to get information that can help in determining how tax loopholes impact Canadian individuals' and small business's behavior [8].

One of the criticisms that surround quantitative research is that the interpretation of data might reflect personal biases of the respondent. The other criticism is that the result of the research might not mirror the reality of what is being investigated. For the purpose of combating 
Citation: Yahya M (2018) Tax Loopholes Impact on Canadian Individuals' and Small Business's Behaviour. J Glob Econ 6: 295. doi: $10.4172 / 2375-4389.1000295$

Page 3 of 3

such limitations, Saunders et al. argues that a quantitative researcher needs to establish trustworthiness in the process of convincing the readers that the findings within a given study are of great significance $[8,9]$. All these aspects are what are commonly described as the reliability and validity of the study. The reliability and validity of this study will be assured through several activities. First, a questionnaire will be developed in a manner that captures all the required content for this study. The pilot study will be conducted using the same questionnaire so as to maximize its clarity, preciseness and relevancy. All the ambiguous questions which fail to show clear objectives for the study will be replaced as deemed appropriate [9]. With such actions undertaken, the research will be very objective and reflect the real situation on the ground regarding the impact of tax loophole on Canadian individuals' and small business's behaviour.

\section{Reflections}

More often than not, most professional papers focus mostly on the general impact of tax loophole on the big corporations' performance and behaviour, without a specific focus on the impact that such loopholes have on individuals' and small business's behaviour in the country. Additionally, the behaviour of individuals and small business owners is very dynamic; hence, findings from the previous studies might vary greatly with the situation on the ground at the moment and might also change in future. This means that the tax loophole in Canada is a volatile situation that can change within the shortest time possible. Thus, the findings of the research can easily be rendered invalid after some time.

Different factors tend to influence individuals and small business people to comply with tax requirements or evade paying tax in different ways. Coming to the conclusion, therefore, that it is only the tax loopholes in Canada that encourage individuals and small business people to avoid paying taxes might be invalid. The same findings cannot be generalized again to all the small business and individuals in the country as each and every person has their own reasons for avoiding paying taxes.

Additionally, like any other research, a number of difficulties are likely to be faced within the whole process of this study. Based on the fact that this will be a cross sectional study, the results present the findings only at one particular time, that is, during the time the study is carried out, and might not present what will happen after and before. Another limitation will be getting the right number of the required sample, which will be very difficult since most individuals and small business owners might fear giving strangers information related to their tax compliance status. The study is also likely to face financial crisis and time constrain, taking into consideration the expenses likely to be involved while the researcher still has other duties and financial responsibilities. The aspects of ethics that guarantee the interviewees freedom to withdraw from the study at will also likely to result in other challenges of getting enough respondents to complete the questionnaires. These challenges in this case will, however, be overcome as specific interventions will be adopted to eliminate each challenge one by one.

\section{Conclusions}

With the overall aim of identifying how tax loopholes impact on Canadian individuals' and small business's behaviour, this research seeks to determine the extent to which income tax loopholes in Canada encourage individuals and small business to avoid paying taxes, provide understanding of Canadian individuals' and small businesses' behaviour with regards to income tax loopholes in the country and, finally, develop recommendations that encourage the government of Canada to change some tax policies and procedures to close the tax loopholes. Systematic review of the existing secondary literatures and questionnaires will be used in collecting relevant information for appropriate findings and conclusions.

\section{References}

1. Bucovetsky S, Haufler A (2008) Tax competition when firms choose their organizational form: Should tax loopholes for multinationals be closed?. J Int Econ York University, Canada 74: 188-201.

2. Marjit S, Seidel A, Thum M (2016) Tax Evasion, Corruption and Tax Loopholes. Ger Econ Rev, University of Bergen, Bergen, Norway 18: 283-301.

3. Morgan-Thomas M (2013) Countering Offshore Tax Evasion: A Comparative Look at Initiatives by the United States, Canada, the United Kingd om and Japan. Int J Bus Soc Sci, Long Island University, USA.

4. Stiglitz J (2013) A tax system stacked against the 99 percent. The New York Times, Columbia University 9: 36.

5. Patel MV (2016) Corporate Tax Inversions: Battling the "Corporate Benedict Arnolds" by Means of Analogizing to an Individual Taxing Regime. McGeorge L Rev 47: 325-641.

6. Saunders M, Lewis P, Thornhill A (2009) Research Methods for Business Students. University of Birmingham, 5th edition, London, Prentice Hall.

7. Creswell JW (2013) Research Design: Qualitative, Quantitative and Mixed Methods Approaches.3rd edition, University of Nebraska-Lincoln, London, Sage.

8. Saunders M, Lewis P, Thornhill A (2007) Research Methods for Business Students. University of Birmingham, 4th edition. London, Prentice Hall.

9. Bryman A, Bell E (2012) Business Research Methods. 3rd edition, Oxford University Press, Oxford. 